\title{
REFORMING FINANCIAL ACCOUNTS IN THE PUBLIC SECTOR: THE CASE OF UNIVERSITIES
}

\author{
Tommaso Agasisti \\ Politecnico di Milano, Milan, Italy \\ Michela Arnaboldi \\ Politecnico di Milano, Milan, Italy \\ and \\ Giuseppe Catalano \\ Politecnico di Milano, Milan, Italy
}

\begin{abstract}
The introduction of accrual accounting in the public sector has been one of the main business-like devices of New Public Management. Governments and researchers have been extremely interested in the merits of accrual accounting since it was first introduced. However, the debate on this reform is still ongoing. This paper is set in this context, and it explores the case of four Italian universities which have voluntarily adopted an accrual system in a context of legislative autonomy for financial accounting practices. The paper's aim is to study the process of adoption of accrual accounting, specifically investigating two elements: (1) what forces led these universities to adopt accrual accounting, and (2) what accounting framework has been used for their financial statements. In order to interpret the empirical evidence the study has made use of institutional theory and, in particular, more recent developments. The results reveal a complex picture in which three forces differently influence the adoption and implementation of accrual accounting: the individual action of 'champions' of accrual accounting, a favourable organisational context and the isomorphism of private organisations.
\end{abstract}

\section{INTRODUCTION}

In the last twenty years, there has been a general tendency in the public sector to reform traditional cash accounting by adopting business-like accrual accounting ${ }^{1}$ 
(see, for example, Jones, Scott, Kimbro and Ingram, 1985; Parker and Guthrie, 1990; Pallot, 1994; Mellett, 1997; Lapsley, 1998; Lapsley and Oldfield, 2001; Lye, Perera and Rahman, 2005). This change is part of New Public Management (NPM) where accounting plays a central role as an instrument to improve public sector performances (Hood, 1991, 1995). The debate on the transformation of financial accounting in the public sector, and in particular on the benefits of accrual versus cash accounting, is extensive and still open. Moreover, the shift from cash to accrual accounting raises several issues concerning both the difficulties of implementing new accounting practices and the benefits derived from the accrual system. The main identified difficulties are related to the recognition and evaluation of assets (Pallot, 1994). For instance, a major problem is the evaluation of resources of historical and cultural value, such as buildings, monuments and libraries, for which there is an ongoing debate about the recognition and the appropriate evaluation method (e.g. cost and fair value). Similar issues have been highlighted by authorities when determining the value of assets such as roads and infrastructures. These common problems have led international accounting associations (e.g. the International Federation of Accountants) to undertake projects to define accounting standards for public organisations (e.g. International Public Sector Accounting Standards - IPSAS). As far as the benefits are concerned, a first claimed advantage is the improvement of internal decision-making processes (see, for example, Ezzamel, Hyndman, Johnsen, Lapsley and Pallot, 2005; Mack and Ryan, 2006). In particular, adopters suggest the fairer picture of economic results (including asset depreciations and amortisations), and the addition of a long-term perspective on organisational resources and debt as being beneficial. A second benefit is an enhanced external accountability. Many researchers have explored this issue, often highlighting a low 'external use' of the annual reports, where the main users remain governments and auditors (Mayston, 1992; Jones, 1992; Ryan, 1998; Jones and Pendlebury, 2004; Barton, 2005).

This shift to accrual accounting also impacts on universities: organisations that are facing continuous challenges concerning accountability and results as part of a wider process for reforming higher education. The earliest and richest stream of research on this topic focused on the process of adoption, examining the external and internal factors that influence the endorsement of accrual accounting by universities (Gray and Haslam, 1990; Cameron and Guthrie, 1993; Pallot, 1994). Gray and Haslam (1990) examined the interaction between the environment and the organisation, recognising that reporting is driven by policy prescription rather then by user demand. They also highlighted a response of university reports to an 'unstable environment' by moving towards more focused reports centred upon the language of finance. Cameron and Guthrie (1993) extended the study by more specifically analysing environmental factors (internal and external) that could influence university annual reporting. Their conclusions (p. 8) showed little evidence of external influences (in particular regulations) and a growing tendency to have more 'commercially oriented reports' as a response to a 'voluntary act' of the studied university. Two recent contributions have revitalised the debate by analysing the adoption, implementation and use of accrual accounting (Venieris and Cohen, 2004; Skærbæk, 2005). Venieris 
and Cohen (2004, p. 200) examined the 'odyssey of introducing accrual accounting and management accounting' in Greek public universities, and provided evidence of several unsuccessful implementations. Skærbæk (2005) also presented a controversial picture in which accrual accounting appears to be a device that is used to conform to the external environment. These contributions have paid marginal attention to the structure of the accounting system and the framework of annual reports, and have neglected the output. An interesting contribution which tried to fill this gap is the study of Flemish universities by Christiaens and De Wielemaker (2003) using the universities' annual accounts as a basis for their analysis.

While recognising the merits of these previous studies, this paper aims at analysing the voluntary adoption of accrual accounting by four Italian universities through a combined methodology, which has recently been claimed as beneficial for accounting studies (Guthrie and Abeysekera, 2006). We have used a content analysis of the annual reports together with semi-structured interviews. The case studies represent a distinctive situation, as the four universities, two public and two private non-profit, voluntarily adopted accrual accounting. Italian regulations do not provide precise rules on the annual financial reports, and the universities are given autonomy to undertake different approaches. The exceptional situation of the four universities which moved to accrual accounting is interpreted from an institutional perspective, analysing the influence of environmental forces (DiMaggio and Powell, 1983), but conceding the importance of the organisational ecology and individual action (Covaleski and Dirsmith, 1988).

This research has two specific objectives: (1) to detect why the universities studied here adopted accrual accounting and (2) to analyse the structure and contents of the annual reports that show the influence of institutional forces. The paper is organised into five sections: first a brief analysis of the Italian higher education context is illustrated; the research is then explained; the third section describes the theoretical framework that was adopted; the fourth section shows the results; and the conclusions are presented in the last section.

\section{RESEARCH APPROACH}

The exploration of the adoption of accrual accounting by Italian universities was carried out using a mixed methodology which combines content analysis and semistructured interviews. The research was divided into three steps: (1) preliminary semi-structured interviews to investigate the reasons behind the adoption of accrual accounting, (2) a content analysis of the annual reports and (3) semi-structured interviews to triangulate the findings obtained from the content analysis. This choice was suggested by previous research into accounting narrative which highlighted the benefits of combining content analysis with other research methodologies that do not share the same methodological weaknesses. Some studies have examined the advantages of carrying out content analysis with semistructured interviews (Abeysekera and Guthrie, 2004; Guthrie, Petty, Yongvanich and Ricceri, 2004; Haigh, Carlin and Guthrie, 2005). This combination has allowed 
Agasisti, Arnaboldi \& Catalano

the authors to have further insights into the differences among accounting reports and to speculate upon their evolution and disclosure. The research was carried out in four universities, two public (PUB1 and PUB2) and two private non-profit institutions (NP1 and NP2). The selection of the two public organisations was straightforward as they are the only public institutions that have adopted the accrual accounting. The non-profit universities were selected on the basis of their accounting history and size. Table 1 reports the main characteristics of the four universities involved in the study.

The semi-structured interviews were carried out face-to-face with key informants in the four organisations and they, on average, lasted one hour in phase 1 and forty minutes in phase 3; several phone interviews were also made during the research to integrate and validate the previous findings. Table 2 shows the informants in each university.

The content analysis refers to the categories of the accounting framework adopted by private companies in Italy, which was the endorsed rationale for all

TABLE I: MAIN CHARACTERISTICS OF THE UNIVERSITIES INVOLVED IN THE STUDY

\begin{tabular}{lcc}
\hline University & Number of Students & Total Income (Million Euros) \\
\hline PUB1 & $<15,000$ & $<250$ \\
PUB2 & $<15,000$ & $<250$ \\
NPI & $25,000-50,000$ & $500-1,000$ \\
NP2 & $<15,000$ & $<250$ \\
\hline
\end{tabular}

TABLE 2: PEOPLE INTERVIEWED IN THE CASE STUDIES

\begin{tabular}{|c|c|c|}
\hline University & Designation & $\begin{array}{l}\text { Wider role in the } \\
\text { accounting innovation }\end{array}$ \\
\hline \multirow[t]{3}{*}{ PUB I } & Administrative director & Initiator \\
\hline & Accounting officer & Implementer and recipient \\
\hline & Head of accounting & Implementer and recipient \\
\hline \multirow[t]{3}{*}{ PUB2 } & Administrative director & Initiator \\
\hline & Head of accounting & Recipient \\
\hline & Accounting officer & Recipient \\
\hline \multirow[t]{4}{*}{ NPI } & Administrative director & Recipient \\
\hline & Member of the academic board & Recipient \\
\hline & Head of accounting & Implementer and recipient \\
\hline & Accounting officer & Recipient \\
\hline \multirow[t]{3}{*}{ NP2 } & Member of the evaluation committee & Recipient \\
\hline & Administrative director & Implementer \\
\hline & Accounting officer & Recipient \\
\hline
\end{tabular}

Note: Initiators indicate people who initiate the introduction of accrual accounting; implementers are people in charge of the actual implementation; recipients are users of the system. 
the universities involved in this study (Italian Civil Code, articles 2423-2427). Italian principles include four documents: the management report, the balance sheet, the income statement(s) and the notes. The management report was studied observing the presence and balance of quantitative and qualitative information, which reflects the universities' use of language (Gray and Haslam, 1990) in the document presentation. The balance sheet and the income statement were examined considering their format and structure, the included items, and the recognition and measurement principles. Research began in 2003 with the preliminary interviews and concluded in 2007 after the follow-up phone interviews. The analysis of the financial statements refers to 2004; no major changes were revealed in the 2005 and 2006 reports.

\section{CONCEPTUAL FRAMEWORK}

The endorsement of accrual principles by the four Italian universities shows a distinctive situation: in a context of complete autonomy, these organisations adopted accrual accounting and thus did not conform to the 'traditional', widespread practice that is cash accounting. The phenomenon is analysed from an institutional perspective, drawing on some more recent developments which recognise an intertwined role of self interests, organisational power and the wider social context forces to 'actively invent and then articulate institutionalized expectations regarding organizational policies and procedures' (Covaleski and Dirsmith, 1988, p. 562; see also Covaleski, Dirsmith and Samuel, 1996; Dacin, 1997).

This section reviews the institutional forces which may suggest answers to the research questions: (1) which forces played a role in the decision to adopt accrual accounting, (2) which model was adopted and (3) why. In discussing these elements we refer to the institutional setting and distinguish three different realms (Carpenter and Feroz, 2001): (1) the wider environment, (2) the organisational environment and (3) individuals.

\section{The Wider Environment}

This first realm refers to institutional contributions which emerged in the late 1970s and early 1980s. These theories developed in reaction to prevailing conceptions of organisations as bounded, relatively autonomous, rational actors. The institutional theory stresses social construction, as individuals and organisations make sense of their everyday purpose in the context of their own wider social environment. The main themes on which the theory is based are summarised by Scott and Meyer (1994) as follows: (1) the visible structures and routines that make up organisations are a direct reflection on, and the effects of, rules and structures built into (or institutionalised within) the wider environment; (2) the dependence of organisations on the patterns built up in wider environments - rather than on a purely internal technical and functional logic - produces organisational forms that 
Agasisti, Arnaboldi \& Catalano

are often rather loosely integrated (or decoupled) structures; (3) the environmental patterns that drive organisational routines through linkages and effects go beyond simple direct control; and (4) the environmental pattern that creates and changes organisations can be described as rationalised and rationalising (Scott and Meyer, 1994, pp. 2-3).

Institutional theory interprets organisational behaviour as a response to external pressures, which force institutions to adopt structures and procedures that are socially widespread and accepted. In this perspective, the organisation as a whole is expected to respond homogeneously. This process is described as isomorphism by institutional theorists: 'a constraining process that forces one unit in a population to resemble other units that face the same set of environmental conditions' (DiMaggio and Powell, 1983, p. 149). This process of legitimation that takes place is known as 'institutional isomorphism' (Meyer and Rowan, 1977; Meyer and Scott, 1992; DiMaggio and Powell, 1983). This is the process by which organisations strive for similarity. DiMaggio and Powell (1983) identify three such processes: coercive, mimetic and normative. The first of these stems from political influence and the problem of legitimacy. Coercive isomorphism can result from formal and informal pressures exerted on organisations, including a government mandate. Mimetic isomorphism results from organisations that adopt standard responses to uncertainty. Normative isomorphism is associated with 'professionalisation'. While DiMaggio and Powell (1983) distinguish between these three strands of isomorphism, they acknowledge that these elements intermingle in empirical settings. In this study, the wider environment is the set of norms and available accounting frameworks that were presented in the research context.

\section{The Organisational Environment}

The institutional perspective presented above has been adopted in several studies into public sector changes and, though often signalling heterogeneity in the organisational response, not all the organisations in the same institutional environment respond in the same way. These situations have led some authors to complement the institutional theory with other perspectives that recognise the role of power and self-interest of the organisational actors. Covaleski and Dirsmith dealt with these issues in their study; they recognised that the accounting choice - the budget in their case - 'represents the positions of the various interest groups concerned with generating resources supplied to the organisation by society and with allocating these resources to the various subunits within the organisation' (1988, p. 566). Power and self-interest are not however seen as antagonistic by institutional theorists. For example, DiMaggio (1988) illustrated their complementarity while distinguishing institutionalisation as an outcome and as a process. Institutionalisation, as an outcome, places organisational practices and characteristics beyond the reach of interests and politics. Expectations of acceptable practices exist in a given environment, and organisations must passively conform to them to maintain legitimacy. Institutionalisation as a process instead 
is more political and it reflects the relative power of organised interests and the actors who mobilise around them.

The mobilisation of power was interestingly depicted by Hardy (1996), who showed four modes in which it can emerge: power over resources; power over decision-making; power over meaning; and power of the system. The first element, power over resources, refers to where actors deploy (or restrict) key resources to modify the behaviour of others. Power over decision-making processes means exerting power over subordinates' participation in decisionmaking. Power over meaning involves influencing actors' perceptions, cognitions and/or preferences so that they accept stability or change (here accounting). Finally, power of the systems refers to the existing, prevalent organisational values, cultures and structure. In relation to the organisational realm, Hardy's conceptualisation of power highlights the need to consider two elements that are relevant in this study to analyse change or stability: the governance model, and the shift in value and culture surrounding the university.

The governance model of Italian universities can be viewed in the context of four main roles: the academic board, which is composed of elected academics; the executive board, in which both academics and external stakeholders are represented (e.g. students, local government actors, industry representatives and chambers of commerce); the rector, the leading governor of the university who is elected by the academics; and finally the administrative director, who is usually appointed by the executive board on a proposal made by the rector. These four actors have different roles and power, and they can significantly influence the accounting decision to change (or not) the accounting system. The second element refers to the influence of changes (or stability) in the values and structure of an organisation. Other studies have shown how the search for organisational efficiency (e.g. Roberts and Greenwood, 1997; Bansal and Bogner, 2002) and major reorganisations (Leblebici, Salancik, Copay and King, 1991; Avgerou, 2000; Arnaboldi and Lapsley, 2004) can implicate, or justify, the adoption of new accounting and managerial techniques.

\section{Individuals}

The role of individuals has been recognised by several authors as influential in the process of institutionalisation of new accounting and managerial practices (e.g. Covaleski et al., 1996; Dacin, 1997; Burns, 2000; Arnaboldi and Lapsley, 2003; Brown, Booth and Giacobbe, 2004). The role of the key actors is closely intertwined with the previously presented concept of power: new ideas remain relegated unless the initiator and the implementer are assigned with considerable power. In particular, firstly, they need financial resources to undertake and deploy the project; secondly, their power over subordinates' participation in decision making may enhance participation in change or stability; finally, the support of other organisational key actors may give meaning to the change by catalysing efforts and attention. This specific issue has been analysed by 
Agasisti, Arnaboldi \& Catalano

Ribeiro and Scapens (2006), who set individuals and power within a wider institutional perspective:

\begin{abstract}
Strategic actors, we suggest, propose representations and deploy strategies that are framed by the existing configuration of the circuits of power (e.g. the existing rules, distributions of resources, and available control devices) (Clegg, 1989), and they may also attempt to promote changes in those configurations. These strategies may in turn lead to new arrangements being introduced in individual organisations. Key organisational decision-makers - the actors responsible for, and able to dispose of, organisational resources - may accept solutions proposed by the enrolling actors; but they could also reject them (Ribeiro and Scapens, 2006, p. 99).
\end{abstract}

The authors highlight three important features in their study: first, the importance of key individuals as initiators in the process of change; second, their dependence on the context which surrounds them, as their action is encouraged or hampered by other institutional forces; and third, the attitude to enrol new 'champions' to effectively lead the change.

In this study there are two key strategic actors who may influence the process of adoption of accrual accounting: the initiator, referring to the person who initially suggests adopting this technique; and the implementer, intended here as the leading actor in guiding the implementation.

\title{
RESEARCH CONTEXT: THE WIDER ENVIRONMENT
}

In Italy, there are two different types of universities, namely public and private, which are regulated - in many areas - by different norms. As far as accounting norms are concerned, throughout the twentieth century, the effects on the two different types of universities will be discussed accordingly. While private universities have always been traditionally free to decide on their accounting procedures, public universities have been subjected, since the 1980s, to different, specific directives provided by the Ministry of Education about the content and the form of accounting reports. A first indication was a decree in 1982 (Decree of the President of the Republic, 4 March 1982, n. 371), which established a common reporting scheme for public universities, and provided a general indication about the adoption of cash accounting.

The situation changed in 1989, when a specific law (D.lgs 168/1989, 9 May 1989, n. 189 - article 7) was set up for the university sector as a whole, which included both private and public universities. With this law the central government stated the autonomy of universities (both public and private), and allowed each institution to set up their own criteria and structures for the annual accounts. Private universities in fact already had autonomy in this field, so the impact of the 1989 decree was rather limited. The main effect was that, for the first time, a national law recognised the existence of a unique university system, in which both public and private institutions operate. While previously 
Reforming Financial Accounts in the Public Sector

TABLE 3: THE ACCOUNTING SYSTEMS IN ITALIAN UNIVERSITIES (2005)

\begin{tabular}{lccc}
\hline & Public Universities & Private Non-Profit Universities & Total \\
\hline Accrual accounting & $2(3 \%)$ & $9(64 \%)$ & $11(14 \%)$ \\
Cash accounting & $62(97 \%)$ & $5(36 \%)$ & $67(86 \%)$ \\
Total & 64 & 14 & 78 \\
\hline
\end{tabular}

Source: Ministry of Education (MIUR) (2005).

the annual reports of public universities were drafted using a cash accounting method, this law offered the possibility of adopting different solutions, such as accrual accounting or intermediate approaches. The roots of the public sector in cash accounting led many universities to maintain a cash system, but some institutions voluntarily decided to shift to accrual accounting. Among the public universities, only two organisations actually transformed their system, while among the private non-profit institutions nine out of 14 used an accrual system - some of them already using it prior to 2005 (see Table 3).

Without affecting the 1989 law, the Ministry of Education and the Ministry of Treasury enacted a decree (decree, 5 December 2000) that obliges public universities to provide a yearly report on incomes and expenses, homogenously defined for each university. Universities may (or may not) continue to maintain the structure of their annual reports but the decree imposes a further task of delivering the document to the central government. The homogenous scheme required by the decree actually forced universities to re-classify their reports according to a cash basis. However, the decree involved only public universities and it again produced a separation in the legislative framework between public and private universities - the latter were not required to submit their report in coherence with the new homogenous scheme. Finally, in 2007 (D.M. 76/2007, 1 March 2007) came a reform in which the Ministry of Education also required private universities to adhere to the homogenous classification of their reports. However there was a significant change because the Ministry defined two different schemes to report data to the ministries: one for universities that have adopted cash accounting and one for universities that have adopted accrual accounting. In this way, each autonomous choice made by universities concerning accounting procedures is respected and the objective is, in the medium-term, to allow each university to report its accounting information coherently with its accounting system, without forcing universities to adopt accrual accounting.

\section{RESULTS: ADOPTION AND OUTCOME}

The findings of this study are presented in two main parts, concerning (1) the adoption of accrual accounting and (2) the outcome (financial reports). The first 
Agasisti, Arnaboldi \& Catalano

part refers to the first research question (why did these universities adopt accrual accounting?). The second part shifts attention from the process to the outcome, presenting the comparison of the accounts published by the four universities. The third part concludes with some insights into the use of data, highlighting different attitudes and paying attention to the various documents, which have voluntarily been implemented.

\section{The Adoption}

The previous section showed that the wider environment provides autonomy, so that the universities may choose their accounting systems. In this setting, the four studied universities decided to endorse accrual accounting, in contrast with the prevailing choice of all the other institutions in Italy. This distinctive picture suggests a complex situation in which the elements of the wider context intermingle with the other two realms identified in the conceptual perspective: the organisational environment and key individuals. Drawing on this pluralistic dialogue, the four following sections present the process of adoption for the four cases and highlight their organisational context (in particular the governance model, values and major changes) and the role of key individuals (initiators and

TABLE 4: THE MAIN ATTRIBUTES OF THE ORGANISATIONAL REALM

\begin{tabular}{|c|c|c|c|c|}
\hline University & PUB I & PUB2 & NP I & NP2 \\
\hline Foundation & Early 1960s & Early 1960s & Early 1900s & Early 1920s \\
\hline $\begin{array}{l}\text { Number of university } \\
\text { campuses }\end{array}$ & 5 & I & 5 & I \\
\hline $\begin{array}{l}\text { Geographical } \\
\text { position of the } \\
\text { campus }\end{array}$ & North & Centre & North and Centre & North \\
\hline $\begin{array}{l}\text { Teaching - research } \\
\text { fields }\end{array}$ & $\begin{array}{l}\text { Cognitive } \\
\text { Sciences, } \\
\text { Economics, } \\
\text { Engineering, } \\
\text { Philosophy, } \\
\text { Law, Science } \\
\text { and Sociology }\end{array}$ & $\begin{array}{l}\text { Architecture, } \\
\text { Medicine, } \\
\text { Law, Science } \\
\text { and } \\
\text { Technology }\end{array}$ & $\begin{array}{l}\text { Agriculture, } \\
\text { Economics, Law, } \\
\text { Arts, Medicine, } \\
\text { Finance, Social } \\
\text { Science, Modern } \\
\text { Languages, } \\
\text { Psychology }\end{array}$ & $\begin{array}{l}\text { Economics, } \\
\text { Business } \\
\text { and Law }\end{array}$ \\
\hline $\begin{array}{l}\text { Accounting } \\
\text { history - practising } \\
\text { accrual accounting } \\
\text { since }\end{array}$ & Mid-1990s & Early 2000 s & $\begin{array}{l}\text { Practised accrual } \\
\text { accounting } \\
\text { when founded } \\
\text { Abandoned in } \\
\text { 1980s } \\
\text { Endorsed again in } \\
\text { early 1990s }\end{array}$ & $\begin{array}{l}\text { Since } \\
\text { foundation }\end{array}$ \\
\hline $\begin{array}{l}\text { Organisational } \\
\text { change }\end{array}$ & None & Early 2000s & During the 1980 s & None \\
\hline
\end{tabular}


Reforming Financial Accounts in the Public Sector

TABLE 5: KEY INDIVIDUALS IN THE PROCESS OF ADOPTION

\begin{tabular}{|c|c|c|c|c|}
\hline University & PUB I & PUB2 & NP I & NP2 \\
\hline Initiator & $\begin{array}{l}\text { Administrative } \\
\text { director }\end{array}$ & $\begin{array}{l}\text { Administrative } \\
\text { director and } \\
\text { rector }\end{array}$ & Academic board & Founders \\
\hline $\begin{array}{l}\text { Current } \\
\text { implementation } \\
\text { system }\end{array}$ & $\begin{array}{l}\text { Internal staff and } \\
\text { external } \\
\text { consultants }\end{array}$ & $\begin{array}{l}\text { Internal staff and } \\
\text { external } \\
\text { consultants }\end{array}$ & $\begin{array}{l}\text { External expert, } \\
\text { enrolled at the } \\
\text { beginning }\end{array}$ & $\begin{array}{l}\text { Internal chief } \\
\text { financial } \\
\text { officer }\end{array}$ \\
\hline
\end{tabular}

implementers). Tables 4 and 5 summarise the main elements that have been dealt with.

\section{PUB1}

The first public university studied - PUB1 - is located in the north-east of Italy and belongs to a province with above-average autonomy. There are only two autonomous provinces in Italy (out of 107), and these have been assigned greater powers by the central government for geographical and historical reasons. The most important deviation from the norm is their ability to establish new laws. PUB1 was founded in the early 1960s by the president of this autonomous province and since the beginning its history has been characterised by a close relationship with the community and the local authorities. This relationship is reflected in the governance model, above all in the executive board, which includes three members of the government of the autonomous province and nine members of other local entities. Furthermore, unlike the majority of public universities in Italy, the executive board has significant power in influencing decision-making processes and in directing the strategic plan of the university. This situation is due on one hand to the history of PUB1 (its foundation above all), but also to the fact that the power of the autonomous province on the university resources is very high (Hardy, 1996). A 1993 provincial law established a privileged link between the university and the authorities, through which the province has the power to assign, yearly, financial resources to action plans that are considered of benefit to the community. Another important element of the PUB1 organisational environment is that a major reorganisation was undertaken in the second half of the 1990s. This was a large project aimed at increasing the autonomy of departments and faculties, and improving the technical and administrative infrastructure to support these centres. The project was divided into four phases and finally ended in 2003. This major revision involved many areas: the organisational structure, information systems, planning and budgeting, and front line support services (in particular student support).

The adoption of accrual accounting was set in this context, in which the desire of PUB1 to appear modern was a priority for both the organisation members and the involved parties, the autonomous province in particular. 
Agasisti, Arnaboldi \& Catalano

However, the specific choice of the accounting systems lies in an individual realm: the director had a strong belief in accrual accounting, as the following comment shows:

Accrual accounting is the best system for our institution and it was essential to achieve the goals of the reorganisation. Accrual accounts allows costs to be determined instead of cash outflows, which allows resources, responsibilities and targets to be associated (Administrative Director at PUB1).

He considered accrual accounting to be the most appropriate instrument to have more refined information on 'revenues and costs', which were seen as prerequisites to increasing the autonomy of the faculties and departments while maintaining their accountability. This situation reflects a common issue for those who have adopted accrual accounting in the public sector: financial accounting is viewed more as a tool for managers than for external accountability. Unlike situations elsewhere, financial accounting in this case was not considered a substitute for management and cost accounting, which had been entirely renovated during the previous reorganisation; the revision of the financial statements was instead seen as essential to complete the innovation path. The implementation of the new system started in 1997 and ended in 1999 and it involved external consultants and internal personnel. The academic board defined a coordination committee which was formed by a professor, delegated by the rector, as the general supervisor; the administrative director as the project leader; and technical and administrative staff (mainly accounting and information systems staff).

The composition of the coordination committee shows that the involvement of staff, including professors and administrative officers, was considered important; the intervention was straightforward and no opposition was witnessed during the interviews. This again is a sign of the role of the 'champion' - the administrative director - using power over meaning (Hardy, 1996): he influenced the actors' perceptions and cognitions within the university to accept accrual accounting as the perfect instrument to achieve modernisation.

\section{PUB2}

The second public university examined - PUB2 - is a very small university located in central Italy in a rather remote city. It is an example of a traditional university in which there are two governing bodies (academic senate and administrative council) which act in a very collegial way. Like many small universities in Italy, the most important source of financing is the state; and this explains why PUB2 directed a great deal of attention to the central government's directives and rules in the sector. However, at the same time, PUB2 wanted 'its own place' in the university system, by innovating its practices in all the activities of the universities: teaching, research and support services.

Innovation in the accounting system was part of this modernisation process, decided on by the university bodies in an attempt to gain higher recognition 
within the university system in Italy. Even though this objective was clearly stated by the governing bodies, they had no specific idea on how to achieve this modernisation. They decided to enrol a new administrative director, who previously worked in the private sector, to innovate the support services and procedures. This choice clearly shows a process of mimicry of the business sector; the governing bodies did not have a clear idea of what they wanted to achieve, but they were convinced that the most efficient solutions could be found in the private sector. The specific choice of introducing accrual accounting was taken by the newly employed administrative director in 2001. A few months after his arrival at PUB2 he signalled the need to change the financial accounting system, as a means of innovating managerial practices:

The existing financial accounting was useless for efficient managing purposes, which instead was a priority of my mandate (past director of PUB2).

He considered accrual accounting as an answer to two main problems: (1) the necessity to attract more resources (the financial analysis showed a gap of about 6 per cent of the total budget) and (2) the re-organisation of the university in order to better trace how the resources were used. The governing bodies agreed with the necessity to solve these two problems, and they posed it as a priority. In this context, the starting point was that the director decided to share his ideas about the necessity of new accounting procedures with the rector and to set up a strong political committee for the process, and then he actively involved the staff in the operative work. After this, the new management also believed that more transparency in analysing the economic activity of the university should be a priority. For this reason, and on the basis of the director's solicitations, they decided to change the entire structure of the accounting process, moving towards the adoption of an accrual system. In this way, they created a new approach, which also permitted the responsibility centres and their objectives to be identified.

Practical implementation was delegated to a committee composed of internal staff and external consultants. Among the important issues to correctly understand the main reasons behind the change in accounting procedures, it is important to point out that the rector and the director decided to immediately clarify that one of the main objectives of accrual accounting was to create an innovative way of distributing resources among the departments. The governing bodies accepted the idea even though a complete and clear model for utilising the information derived from accrual accounting was not developed in the first stage. Only later was a rector's delegate charged with creating a new system within the accrual accounting framework to link objectives and resources; the accruals permitted the resource flows and related performance to be analysed more transparently.

From an examination of the PUB2 case study through the use of an institutional theory approach to interpret this university's experience, it can be stated that the key issue at PUB2 was the desire to introduce some innovation into a traditional (and completely non-innovative) context. In the governing body's mind, accounting procedures represented an effective way of introducing new ideas and objectives. 
Agasisti, Arnaboldi \& Catalano

\section{NP1}

NP1 is a non-profit university which was established by a foundation. Its main campus is located in the northern part of Italy, but it also has another important campus in Rome where there is the faculty of medicine. Considering the total number of students, NP1 can be defined as a medium-large university, with more than 40,000 students. The foundation which established the university is the owner of the assets and it also plays a prominent role in financing some particular activities.

A brief history of this institution's accounting experience is useful in understanding the decision to change to accrual accounting.

Until 1976, NP1 had not published its own separate annual report, but its financial results were included in the foundation's report. This decision was mainly driven by financing reasons, in particular the need to cross-subsidise the medicine faculty. The foundation had opted for an accrual accounting system. In 1976 the foundation, which includes both the university and a hospital, decided to publish two separate accounts, to deal with the new requirements of the Italian government, which involved presenting financial data for the hospital on a cash basis. Although NP1 initially maintained the accrual basis, in the middle of the 1980s they decided to move to cash accounting. The accounting change, however, created several problems concerning the adjustments that were necessary to the information systems as these were only partially updated.

At the beginning of the 1990s, a specific event occurred: the election of new academic and executive boards. This occasion represented a break with the past, as the new boards recognised the difficulties and the lack of transparency of their 'hybrid' accounting system. In particular, a very authoritative member of both boards, who was a manager in important private companies, suggested undertaking a major revision of the accounting system, and moving towards more transparent procedures, "which should be inspired by the accounting habits of the private sector'. The executive board agreed with the views expressed by this influential member - the initiator - and the decision was taken and first pursued with the enrolment of a new financial manager, whose priority was to revise the accounting system.

With the aim of coherently following the board's suggestion, it was decided to look for a new financial manager from the business sector. Consequently, the industrial background of this new manager reflects the desire to mimic the business sector. The 'champion' of financial accounting immediately suggested moving to accrual accounting as an answer to several issues: liquidity, economic results, and asset and liability appraisal. Furthermore, the system appeared to be suitable to enhance external accountability, which was the main issue for the university board.

Without the strong commitment provided by the boards, more specifically by their most authoritative and influential members, I think it would have been impossible to change the dramatically confused accounting system which was operating when I was hired (past financial director of NP1). 
Among the main objectives for the accounting system suggested by the boards was that of reporting tangible and intangible assets. Moreover, NP1 also had assets with a strong cultural and historical value (antiquities, collections, monuments, etc.). In addition, as NP1 is the oldest university of the four universities studied, it is understandable that accounting procedures which capitalised heritage assets already existed there. Other recent universities, instead, tend not to capitalise their library stocks, for example, but rather expense them given that the asset value is not sufficiently high to justify the more complicated administration of the library stocks as an asset.

\section{NP2}

NP2 is a well-known non-profit university located in the north-west of Italy. Since its foundation at the beginning of the 1900s, the university has gained an international reputation, and its business school is ranked as one of the most important in Italy. This image of efficiency and high quality of teaching is a major aim of the university, which relies on students' fees as a major source of financing.

Both the documents and interviews showed that the executive board plays a major role in the strategic and operational decisions of the university. The executive board is composed of nineteen members: ten of these members belong to a foundation, which is the main financer of the university.

Sources of finance are particularly important to NP2, which mainly relies on two inflows: the financial support of the foundation and students' fees. These two elements of the organisational environment are reflected in the management processes, as the following comment of the accounting director shows:

The executive board is very interested in obtaining a transparent and precise picture of how we spend the money, they want to be sure that the margin of the commercial activity is positive. They also put pressure on controlling student receivables and even in monitoring their progress; students who have enrolled but do not pay the subsequent fees are considered a cost for the university and a risk for our image (financial manager at NP2).

The accounting history of NP2 shows a linear trend. Accrual accounting was adopted when the university was first established. The choice was influenced by its founders who were mainly involved in the private sector. Accrual accounting was considered the ideal system to provide external accountability to its financers. This continuity also emerged during the interviews, in which managers highlighted how accrual accounting is the only system to have been considered. The existing information system was revised in the middle of the 1990s; the annual report structure has not changed significantly, but it has been constantly amended to maintain an alignment with private-sector legislation (not compulsory for them) and to shape the report with a 'more modern' image, as the financial manager said, an image in which accrual accounting is 'the only way to present financial results' (financial manager at NP2). 
Agasisti, Arnaboldi \& Catalano

\section{The Outcome: The Financial Statements}

All the four universities decided to endorse the framework and the principles adopted in the civil code by Italian private companies. This decision was straightforward in all the institutions as it was considered, at the time of adoption, as the most diffused and consolidated approach - suggesting the presence of a mimetic and isomorphic behaviour by universities (DiMaggio and Powell, 1983). This section presents the results of the financial statement analysis while making a double comparison: first with the general framework of companies (if and how they diverge); and second with the university statements. The content analysis was conducted using a technical approach (Christiaens and De Wielemaker, 2003) and it reflects the conceptual perspective and shows the influence of the previously defined three forces: the environment, the organisational field and the individual.

The civil code requires four documents to be included: the management report, the balance sheet, the income statement and the notes. Table 6 summarises the differences in the general presentation and structure. First the dimension of the reports differ in a range from 68 to 131 pages. The balance between the documents is not homogeneous either, and different emphasis has been placed on the elements included. For example PUB1, PUB2 and NP1 dedicate a significant part of their reports to the notes ( 55 per cent, 70 per cent and 70 per cent respectively), while NP2 highlights the management report by dedicating 22 pages to it (32 per cent).

A different emphasis on these elements also emerges from the order of presentation in Table 6 . The two non-profit universities follow the order adopted by Italian accounting principles for industrial companies: management report, balance sheet, income statement, notes, and other documents. PUB1, instead, places the balance sheet and the income statement at the beginning of the report without any introduction, leaving the explanations to the subsequent sections.

TABLE 6: SIZE AND STRUCTURE OF THE ANNUAL REPORTS

\begin{tabular}{lcccc}
\hline & $\begin{array}{c}\text { PUB I } \\
\text { No. of pages } \\
\text { (\% of total) }\end{array}$ & $\begin{array}{c}\text { NPI } \\
\text { No. of pages } \\
\text { (\% of total) }\end{array}$ & $\begin{array}{c}\text { PUB2 } \\
\text { No. of pages } \\
\text { (\% of total) }\end{array}$ & $\begin{array}{c}\text { NP2 } \\
\text { No. of pages } \\
\text { (\% of total) }\end{array}$ \\
\hline Management report & - & 16 & 29 & 22 \\
Balance sheet & 4 & $(14 \%)$ & $(24 \%)$ & $(32 \%)$ \\
Income statement & $(5 \%)$ & 2 & 4 & 1 \\
& 3 & $(2 \%)$ & $(1 \%)$ & $(1 \%)$ \\
Notes & $(4 \%)$ & $(2 \%)$ & 5 & 1 \\
& 42 & 32 & $(1 \%)$ & $(1 \%)$ \\
Other documents & $(55 \%)$ & $(70 \%)$ & $(70 \%)$ & 34 \\
Overall size & 28 & 14 & 13 & $(50 \%)$ \\
& $(36 \%)$ & $(12 \%)$ & $(2 \%)$ & $(15 \%)$ \\
& 77 & 114 & 131 & 68 \\
& $(100 \%)$ & $(100 \%)$ & $(100 \%)$ & $(100 \%)$ \\
\hline
\end{tabular}


Reforming Financial Accounts in the Public Sector

TABLE 7: SUPPLEMENTARY DOCUMENTS

\begin{tabular}{|c|c|c|c|c|}
\hline Total Size & $\begin{array}{c}\text { PUB I } \\
28 \text { pages }\end{array}$ & $\begin{array}{c}\text { NPI } \\
\text { I } 4 \text { pages }\end{array}$ & $\begin{array}{l}\text { PUB2 } \\
\text { 13 pages }\end{array}$ & $\begin{array}{c}\text { NP2 } \\
10 \text { pages }\end{array}$ \\
\hline \multirow[t]{3}{*}{ Documents } & $\begin{array}{l}\text { Cash flow } \\
\text { statement }\end{array}$ & $\begin{array}{l}\text { Cash flow } \\
\text { statement }\end{array}$ & $\begin{array}{l}\text { Balance sheet } \\
\text { and income } \\
\text { statement } \\
\text { divided into } \\
\text { units }\end{array}$ & $\begin{array}{l}\text { Income statement } \\
\text { for commercial } \\
\text { activities }\end{array}$ \\
\hline & $\begin{array}{l}\text { Cash flow } \\
\text { management }\end{array}$ & $\begin{array}{l}\text { Statistics } \\
\text { (Historical trend } \\
\text { of key economic } \\
\text { figures; students' } \\
\text { taxes) }\end{array}$ & $\begin{array}{l}\text { Report of } \\
\text { external } \\
\text { auditors }\end{array}$ & $\begin{array}{l}\text { Report of } \\
\text { external } \\
\text { auditors }\end{array}$ \\
\hline & $\begin{array}{l}\text { Use of resources } \\
\text { by function } \\
\text { Report on the } \\
\text { Agreement } \\
\text { Programme } \\
\text { with the } \\
\text { Autonomous } \\
\text { Province }\end{array}$ & & & $\begin{array}{l}\text { Cash flow } \\
\text { statement }\end{array}$ \\
\hline
\end{tabular}

All the universities include additional documents which are reported in Table 7 in the order they appear in the reports. It is interesting to note that the two public universities included documents on the use of resources, reflecting the influence of the wider context: the government which requires more accountability on the use of public money. PUB1, in particular, includes five tables and two graphs showing the allocation of resources to activities, projects and organisational units. This choice reflects the individual desire of the two champions at PUB1 and PUB2 to adopt accrual systems to increase accountability for university departments, but their contents also show the influence of the forces in the organisational environment. This is particularly evident at PUB1, which included another document, the 'Report on the Agreement Programme with the Autonomous Province'. This part included a comment and two long and detailed tables on how the university spent the resources allocated by the province; this is a particular situation originated by the power of the province on decision-making and resources (Hardy, 1996).

The organisational environment and in particular the power of governing bodies also emerges at NP1, which produces an income statement for commercial activities as a supplementary document. The interviewees highlighted the importance of this document to the executive board:

Accrual accounting, as I said, is the only possible system here. During the executive committee meetings board members want to see the revenues and costs and in particular they are interested in seeing their division between institutional and 
Agasisti, Arnaboldi \& Catalano

commercial activities; the final line of the income statement of commercial activities, the net margin, is the first figure they look at (accounting director at NP1).

The same situation emerged at NP2: the implementer decided to add a final section on statistics in which detailed tables and graphs show the trend in students' taxes and in key economic figures:

We employed accrual accounting for transparency reasons to offer a real picture of revenues and costs to the executive and academic board; the most important figure is the value added (administrative director at NP2).

Finally, it is important to note that PUB2 and NP2 decided to have an external certification by auditors, a procedure that is not compulsory for universities.

The format and the structure of the balance sheet is quite similar in the four reports. All universities use a two-sided horizontal format, first presenting assets and then equity and liabilities. The assets are composed of fixed assets, current assets, prepayments and accrued incomes. The equity and liabilities are divided into capital and reserves, provisions for liabilities and charges, a specific item of the Italian legislation - Trattamento di Fine Rapporto (TFR) - which is a staff-leaving indemnity, debts, accruals and deferred costs. This situation is somewhat homogenous among the four case studies, which reflects the consolidated structure for industrial companies defined by the Italian Civil Code. Table 8 summarises the macro-items of the balance sheet, according to the Civil Code.

If we examine the items in detail, a first difference can be seen in the presence of the 'unpaid subscribed capital' in the balance sheet of the two public universities; this situation is determined by the desire to perfectly embrace the business frameworks, but also by the most recent developments of accrual accounting. NP1 and NP2 have longer histories in this field, which allowed them to adjust the items to their needs. However, the most interesting difference is the recognition of the library among the assets. As highlighted by Christiaens and De Wielemaker (2003), each university has one or several libraries containing publications, which may have a high cultural and historical value. There are three main decisions a university needs to make considering libraries: its recognition as an asset, its inclusion as a fixed asset or

TABLE 8: THE BALANCE SHEET: MACRO-ITEMS ACCORDING TO THE ITALIAN CIVIL CODE (ARTICLE 2424)

\begin{tabular}{ll}
\hline Assets & \multicolumn{1}{c}{ Liabilities } \\
\hline A) Unpaid subscribed capital & A) Capital and reserves \\
B) Fixed assets & B) Provisions for liabilities and charges \\
C) Current assets & C) Staff leaving indemnities (TFR) \\
D) Prepayments and accrued incomes & D) Creditors \\
& E) Accruals and deferred incomes \\
\hline
\end{tabular}


inventory, and the evaluation criteria. The four cases studied show that only one university (NP1) explicitly accounts for the library, which is classified as a tangible asset. This choice was motivated by the implementer at NP1 for two main reasons: first to show the value to the stakeholders and second to explain the high cost of maintenance of old books and cultural assets shown in the income statement. The following paragraph reports the words of the administrative director on this topic, in which the pressure of organisational forces in shaping the accounting is clear:

In our library we have text books, we have old books and we even have Egyptian papyri. It is important to show the value we possess to the executive board. Furthermore they can better understand why we need to spend money on maintenance each year (administrative director at NP1).

The choice of the other universities is due to their more recent foundation and the presence of a lower library value; they consider the annual purchase of books as a cost because the asset value is not sufficiently high to justify the more complicated administration of the library as an asset.

A final difference in assets is in the presentation of receivables. Three universities (NP1, PUB1 and PUB2) include the Ministry of Education in debtors and highlight a particular item called 'payable by the Ministry'. One university (NP2) also includes the students as debtors, highlighting an item, 'credits towards students', which involves the amounts still due for tuition fees. This situation reflects the organisational environment at NP2, in which the executive board is particularly interested in commercial activities originating from teaching, and also because of a strong financial dependency on tuition fees. As shown during the interviews, receivables from students are closely monitored and when there are delays in students' payments, demand notes are sent and phone calls are made.

Analysing equity, significant differences can be noted with the private sector framework; this is justified by the necessity to tailor the Civil Code scheme, which does not exactly fit the university setting. Table 9 shows the structure of equity of the four organisations. Comparing the four universities, the first difference is the number of items included, ranging from PUB1 with six elements to PUB2 with ten items. There is, however, a main difference in the structure of equity: NP1 and PUB2 divide their capital into restricted and non-restricted capital, with PUB2 explicitly indicating the nature of these restrictions (introduced by third parties or governing bodies). If we look at PUB2's case, its particular history, which explains the adoption of accrual accounting, also sheds more light on the particular characteristics of the adopted reports. Its schemes are in fact those that adhere most to those prescribed by the Civil Code (for example, PUB2 is the only university which explicitly reports the 'amounts related to third party properties', as mentioned in the Code). This behaviour is probably justified by the particular characteristics of PUB2, that is, the promoter of the change (the director) had a long experience in companies which adopted reports defined by the Civil Code. 
Agasisti, Arnaboldi \& Catalano

It is interesting to note that different categories are classified as 'capital' (see in particular university PUB2, item II):

- 'initial capital'; this item is conceptually equivalent to the initial subscribed capital in a business company

- 'contributions', which are amounts or facilities provided by third parties as donations to the universities

- 'funds', which are amounts provided by third parties or accumulated by the universities themselves, usually for a specific purpose (for instance, grants for students, expenses for the formation of the staff, etc.)

If we analyse the liabilities, a first (minor) difference concerns provisions for liabilities and charges. University NP2 only uses two lines: 'provision for taxation' and 'other provisions'. Universities PUB1 and PUB2, on the other hand, adopt three

TABLE 9: CLASSIFICATION OF CAPITAL AND RESERVES

\begin{tabular}{|c|c|c|c|}
\hline $\begin{array}{l}\text { PUB I } \\
\text { EQUITY }\end{array}$ & $\begin{array}{l}\text { PUB2 } \\
\text { EQUITY }\end{array}$ & $\begin{array}{l}\text { NPI } \\
\text { EQUITY }\end{array}$ & $\begin{array}{l}\text { NP2 } \\
\text { EQUITY }\end{array}$ \\
\hline I. Initial fund & I. Non-restricted capital & I. Non-restricted equity & Initial fund \\
\hline III. Reserves & A. Initial fund & A. Initial fund & Ordinary reserve \\
\hline $\begin{array}{l}\text { VI. Statutory } \\
\text { reserves }\end{array}$ & $\begin{array}{l}\text { B. Profit or loss for the } \\
\text { year }\end{array}$ & B. Revaluation reserves & $\begin{array}{l}\text { Extraordinary } \\
\text { reserve }\end{array}$ \\
\hline $\begin{array}{l}\text { VII. Other } \\
\text { reserves }\end{array}$ & $\begin{array}{l}\text { C. Profits or losses } \\
\text { brought forward }\end{array}$ & $\begin{array}{l}\text { C. Additional paid in } \\
\text { capital }\end{array}$ & Revaluation reserve \\
\hline $\begin{array}{l}\text { VIII. Profit or } \\
\text { loss for } \\
\text { the year }\end{array}$ & $\begin{array}{l}\text { D. Non-restricted capital } \\
\text { contributions }\end{array}$ & $\begin{array}{l}\text { D. Profit or loss for } \\
\text { the year }\end{array}$ & Risk reserve \\
\hline \multirow{7}{*}{$\begin{array}{l}\text { IX. Profits or } \\
\text { losses } \\
\text { brought } \\
\text { forward }\end{array}$} & E. Reserves & $\begin{array}{l}\text { II. Capital with } \\
\text { temporary } \\
\text { restrictions }\end{array}$ & $\begin{array}{l}\text { Fund for teaching, } \\
\text { training and } \\
\text { research }\end{array}$ \\
\hline & II. Restricted Capital & $\begin{array}{l}\text { III. Capital with } \\
\text { permanent } \\
\text { restrictions }\end{array}$ & $\begin{array}{l}\text { Profit or loss for } \\
\text { the year }\end{array}$ \\
\hline & $\begin{array}{l}\text { Funds restricted by third } \\
\text { parties }\end{array}$ & & \\
\hline & $\begin{array}{l}\text { Funds restricted by the } \\
\text { decisions of the } \\
\text { governing bodies }\end{array}$ & & \\
\hline & $\begin{array}{l}\text { Contributions restricted } \\
\text { by third parties }\end{array}$ & & \\
\hline & $\begin{array}{l}\text { Contributions restricted } \\
\text { by the decisions of the } \\
\text { governing bodies }\end{array}$ & & \\
\hline & Restricted reserves & & \\
\hline
\end{tabular}


Reforming Financial Accounts in the Public Sector

\section{TABLE I0: THE ITEMS INCLUDED IN MACRO- ITEM C (CREDITORS)}

\begin{tabular}{lc}
\hline University & Number of Items \\
\hline PUBI & 12 \\
PUB2 & 12 \\
NPI & 9 \\
NP2 & 4 \\
\hline
\end{tabular}

lines, including 'provision for pensions'. Finally, university NP1 divided provisions into six sub-items. The remaining main item in liabilities is debt. Here there are two differences. First NP2 places more attention on the payment time, being the only one to separately indicate the debts due and payable within the year or over the year. This is again related to the pressure of the executive board which is always worried about the image of NP2 regarding external stakeholders. A second difference is the number of items included in payables (see Table 10). The higher number (12) in the two public universities is related to the past cash accounting practice where the details of the cash outflows were very high. NP1 also suffers from its recent move from cash to accruals, while NP2 limits the details to four items.

Lastly, NP2 includes the item 'deferred income by students for tuition fees' in the accruals, but this item is not clearly shown in the three other reports. This is again a reflection of the organisational environment, that is, the executive board, who are particularly interested in monitoring teaching and commercial activities.

An analysis of the measurement principles has revealed a substantial uniformity of the initial valuation principle, though there are no specific regulations or recommendations on them. The methods adopted for the main items - tangible assets and intangible assets - are recognised at the original (historic) cost; debts towards customers are measured at the expected future values.

There are, however, several differences in the subsequent valuation. The first one concerns the criteria for depreciation of tangible assets: three universities (PUB1, PUB2 and NP1) adopt a depreciation rate that is proportional to the use of the assets, while NP2 adopts a method based on constant yearly values. A further diversity is in short-period investments: PUB2 uses the cost method, NP2 the market value, and NP1 the lower value between historical costs and market values. Finally, different methods are also adopted for debt: NP1 appraises them at the expected future values, while the others use the nominal values.

\section{The Income Statement}

The format of all four university income statements is vertical. It is interesting to note that the Italian professional body suggests, for the non-profit sector, that one articulates the income statement with a horizontal structure and according 
Agasisti, Arnaboldi \& Catalano

to its functions (CNDC, 2001). Each of the implementers in the four universities clearly stated that they preferred to use a private company system as they have a longer accrual accounting history and are considered the most modern organisations.

A major difference can be noted among the universities: NP2, PUB1 and PUB2 present the income statement based on the nature of the items of revenue and expense, while NP1 discloses operating results by function. This choice was motivated by the informants for two reasons, due to the different influences of specific organisational approaches: first, at the time of adoption private companies in Italy were not allowed to use a presentation by function system and, although not obliged to, they decided to follow this scheme; second, this presentation helps the stakeholder more clearly to understand the accounts in the shift from cash accounting, where the costs are presented by nature.

NP1 instead presents operating results and distinguishes costs by function; it defines a 'prime margin', highlighting revenues and costs from teaching and research, and a 'second margin', from which support service costs are also removed. This presentation reflects the organisational power of the administrative board, which immediately needs to see the margin of the commercial activities.

Another difference is the detailed analysis of the operating costs. While PUB1, NP1 and NP2 have 28, 33 and 23 sub-items respectively, PUB2 presents the costs in more detail, with 61 sub-items. This situation is related to the specific use of financial accounts at PUB2 and the pressure of the governing bodies: accrual accounting was implemented for managerial use, in particular to highlight cost consumption by the different departments and to assign financial resources on the basis of their efficiency. Details and transparency in analysing and showing the costs was a prerequisite to support the decision to change the internal method for allocating resources.

\section{The Notes}

The notes is the third document required by the Italian Civil Code. The regulations indicate the minimum content of the notes, which has the aim of providing additional and more detailed information on the balance sheet, income statement and other facts relevant to better understand the financial and economic situation of the organisation. All the studied universities enclose the notes; the length of this part ranges from 13 to 42 pages, showing common characteristics but also some differences. The structure of the notes is illustrated in Table 11.

Table 11 shows that all the studied universities have at least two common sections: measurement principles and further specification of the financial accounts (balance sheet and income statement). This is normal practice among the universities and also in the private sector.

There are only two notable differences. The first difference is the presence, in NP1, of the principles for consolidating accounting (B) and the principles for attributing mixed costs $(\mathrm{C})$. Both documents are related to a particular feature of 
TABLE I I:THE SECTIONS INCLUDED IN THE NOTES

\begin{tabular}{|c|c|c|c|c|c|}
\hline PUB I & & PUB2 & & NPI & NP2 \\
\hline $\begin{array}{l}\text { A) Measurement } \\
\text { principles }\end{array}$ & A) & $\begin{array}{l}\text { Measurement } \\
\text { principles }\end{array}$ & A) & $\begin{array}{l}\text { Measurement } \\
\text { principles }\end{array}$ & $\begin{array}{l}\text { A) Measurement } \\
\text { principles }\end{array}$ \\
\hline $\begin{array}{l}\text { B) Analysis of the } \\
\text { main items } \\
\text { included in the } \\
\text { balance sheet }\end{array}$ & B) & $\begin{array}{l}\text { Analysis of the } \\
\text { main items } \\
\text { included in the } \\
\text { balance sheet }\end{array}$ & B) & $\begin{array}{l}\text { Analysis of the } \\
\text { main items } \\
\text { included in the } \\
\text { balance sheet }\end{array}$ & $\begin{array}{l}\text { B) Principles for } \\
\text { consolidating } \\
\text { accounting }\end{array}$ \\
\hline \multirow[t]{2}{*}{$\begin{array}{l}\text { income } \\
\text { statement }\end{array}$} & C) & $\begin{array}{l}\text { Analysis of the } \\
\text { main items } \\
\text { included in the } \\
\text { income } \\
\text { statement }\end{array}$ & C) & $\begin{array}{l}\text { Analysis of the } \\
\text { main items } \\
\text { included in the } \\
\text { income } \\
\text { statement }\end{array}$ & $\begin{array}{l}\text { C) Principles for } \\
\text { attributing } \\
\text { mixed costs }\end{array}$ \\
\hline & D) & $\begin{array}{l}\text { Amounts related } \\
\text { to third party } \\
\text { properties }\end{array}$ & & & $\begin{array}{l}\text { D) Analysis of the } \\
\text { main items included } \\
\text { in the balance sheet } \\
\text { and income } \\
\text { statement }\end{array}$ \\
\hline
\end{tabular}

NP2 specificity: the presence of a hospital (in which teaching and research activities are conducted in medical sciences) and several controlled organisations. Section B therefore illustrates the principles for consolidating the university and hospital accounts while section $C$ shows the criteria used to apportion overheads to some autonomous organisations controlled by the university.

\section{CONCLUSIONS}

This paper has examined the adoption of accrual accounting in the Italian public sector, in particular addressing the case of universities. This is an important and unresolved topic which has been raising interest and concern among both practitioners and researchers for twenty years. Accrual accounting has been placed in the set of NPM business-like devices that may be enacted by public and non-profit organisations to achieve enhanced internal management and fairer external accountability. However, a number of authors have questioned the adoption of private sector accounting in a public sector context and have highlighted problems in the implementation and the scarce use of data (see, for example, Mellett, 1997; Barton, 2005). This research contributes, using a technical approach, to this still lively debate by presenting the process and the output (the annual reports) of the voluntary adoption of accrual accounting in four Italian universities which endorsed the scheme in a context of accounting autonomy.

Both the investigation of the process and the content analysis of the annual reports were interpreted by using institutional theory and in particular some recent developments which recognise the role of power and individual actors in the process of institutionalization (e.g. Covaleski and Dirsmith, 1988). We have 
Agasisti, Arnaboldi \& Catalano

highlighted three different 'realms' that may influence the choice and the format of the accrual accounts: the wider environment, the organisational ecology and the contribution of individual key actors (in particular the initiators and the implementers). The main findings of this study are related to the adoption phase and the resulting outcome (the report structure and content). The three realms are intertwined in the adoption phase, however, with a predominance of the organisational and individual forces.

As discussed in the conceptual framework, often the adoption of managerial and accounting techniques follows an isomorphic pressure, mirroring the practices and structures which are most successful in the wider environment (Scott and Meyer, 1994). The environmental stage in which these four universities are set instead did not provide major pressures to adopt accrual accounting. Referring to the three isomorphic processes described by DiMaggio and Powell (1983), the external forces appear limited: there are no specific laws imposing or 'suggesting' a move to accrual accounting; there are no legitimated professional bodies pressurising universities towards accrual accounting; and the majority of the organisations in the field (public and non-profit) still use cash accounting. The only environmental forces that emerged in the adoption is the mimicry of the private sector: accrual accounting is seen by all four universities as a 'modern' tool; its adoption was seen by the universities as a means to legitimate themselves as modern institutions.

The findings have instead shown that the forces which most influenced the adoption of the accrual system concern the organisational environment. As evidenced in the literature discussion, several authors regard these forces as central to the process of adoption of managerial techniques (Covaleski and Dirsmith, 1988, Covaleski et al., 1996; Dacin, 1997). These authors complement the initial vision of institutional theorists, which tend to depict institutions as passively reacting to their external environment This issue was highlighted also by DiMaggio (1988), who conceded that by focusing on the process, institutionalisation often reflects the relative power of organised interests and actors within the organisations. Organisational power, exerted in different forms (Hardy, 1996), is at the centre of this second realm of forces and it is confirmed by this study. In all four universities the adoption of accrual accounting was an answer to the needs of the governing bodies to have higher transparency and accountability (both internal and external), and a more modern image (in particular PUB1 and PUB2). The key actors in the governing bodies were different: the autonomous province for PUB1, the rector for PUB2, the whole executive board for NP2 and a leading business manager in the executive board at NP1. In the first three situations their influence was mainly related to the power over resources and decision making (Hardy, 1996); at NP1, the power exerted by the member of the executive board was more over the meaning of accrual accounting for the university. A common characteristic in the adoption of accrual accounting at PUB1 and PUB2 was that this innovation was part of a wider strategy to modernise their university.

Finally it is important to highlight the importance of the individual's action. This third realm is strictly related to the organisational power as highlighted by Ribeiro and Scapens (2006, p. 99): 'strategic actors propose representation and deploy strategies that are framed by existing configurations of the circuit of 
powers'. In all the institutions in this study there were key actors who suggested specifically that the universities adopt accrual accounting, marrying or initiating the desire expressed by the governing bodies. At PUB1 and PUB2 the specific choice of accrual accounting was made by the administrative directors, seeing in this technique an answer to the desire of the governing body for higher transparency in the accounts. At NP1 and NP2 the initiators were key actors within the governing bodies. They strongly suggested endorsing accrual accounting, interpreting and directing the desire of the whole governing bodies: at NP2 this was an initial decision at the foundation of the university; while at NP1 the move was suggested by an influential member of a newly elected executive board, following the perceived need for higher transparency in financial data.

The second main area of findings is related to the outcome: the content and structure of the annual reports. The outcome again reflects the forces that come from the three realms. The influence of the wider environment seems to be more significant here than in the adoption phase: all the universities adopted the framework of private sector companies. Once the decision to move to accrual accounting was made, the choice of specific framework among the array available was considered obvious by all the universities: they all favoured the most diffused widespread practice without making an evaluation of the other available schemes (e.g. the framework for non-profit organisations). This behaviour signals the process of mimicry described by institutional theorists through which organisations try to legitimate and depict themselves as modern (Scott and Meyer, 1994).

This general framework, imported from the private sector, was then tailored by each university differently, putting emphasis on different parts of the financial reports. The role of the individual actors, specifically the implementers, was crucial in this process of translation: they emerged clearly as 'interpreters' of the organisational powers and needs, framing different desires of the governing bodies (Ribeiro and Scapens, 2006). In the two public universities the main need of the governing bodies was to provide higher transparency in the financial reports: for PUB1 being accountable to its major stakeholder - the autonomous province; for PUB2 providing a clearer picture of financial data internally. These objectives are reflected in the accounts. PUB1 included sections in order to be accountable towards the autonomous province; PUB2 included more details on operational cost for internal accountabilities among the departments.

The role of 'interpreter' of the governing body's desire is shown also in the structure and content of the annual report at NP1. The executive board, which is composed of several financers, wanted a clear picture of the margin created by the university. The structure of the income statement reflects this need, evidencing a 'prime margin', highlighting revenues and costs from teaching and research, and a 'second margin', from which support service costs are also removed.

Finally at NP2, the key individual in the implementation - the administrative director - tailored the annual report to satisfy the desire of the executive board to have a complete picture of the resources of the university. For instance, this is the only university which decided to included the library within the assets; despite the difficulties in evaluating this type of asset, the implementer decided to appraise and to place emphasis on this item, responding to two needs of the 
Agasisti, Arnaboldi \& Catalano

governing bodies: showing externally the value of the assets held by the university (such as ancient books and papyri) and explaining the high cost of maintenance included in the income statement. The two sets of results discussed here highlight that accrual accounting can take on different shapes, according to different needs, and are mainly used as a response to the ecology more than to the wider environment; this may be an important element that policy-makers should take into consideration when they impose such a system.

\section{NOTE}

1 Accrual accounting is defined by Connolly and Hyndman (2006, pp. 272-273) as 'a method of recording expenses as they are incurred and income as it is earned during an accounting period (in contrast to cash accounting which records cash payments and receipts when they are made or received). A major aspect of accruals accounting is that there is much greater emphasis placed on the use and recording of capital assets'.

\section{ACKNOWLEDGMENTS}

We are grateful to the Italian Ministry of Universities for the financial support to this research, part of the larger project 'Le procedure contabili ed il controllo di gestione nelle università italiane', coordinated by the Politecnico di Torino, Department of Production Systems and Business Economics. We also acknowledge the useful suggestions provided by two anonymous referees.

\section{REFERENCES}

Abeysekera, I. and Guthrie, J. (2004). Human Capital Reporting in a Developing Nation: An Analysis of Practice, British Accounting Review, Vol. 36, No. 3, pp. 251-268.

Arnaboldi, M. and Lapsley, I. (2003). Activity-Based Costing, Modernity and the Transformation of Local Government, Public Management Review, Vol. 5, No. 3, pp. 345-375.

Arnaboldi, M. and Lapsley, I. (2004). Modern Costing Innovations and Legitimation: A Health Care Study, Abacus, Vol. 40, No. 1, pp. 1-20.

Avgerou, C. (2000). IT and Organizational Change: An Institutionalist Perspective, Information Technology and People, Vol. 13, No. 4, pp. 234-262.

Bansal, P. and Bogner, W. C. (2002). Deciding on ISO 14001: Economics, Institutions, and Context, Long Range Planning, Vol. 35, No. 3, pp. 269-290.

Barton, A. (2005). Professional Accounting Standards and the Public Sector-a Mismatch, Abacus, Vol. 41, No. 2, pp. 138-157.

Brown, D.A., Booth, P. and Giacobbe, F. (2004). Technological and Organizational Influences on the Adoption of Activity-Based Costing in Australia, Accounting and Finance, Vol. 44, No. 3, pp. 329-356.

Burns, J. (2000). The Dynamics of Accounting Change Inter-Play Between New Practices, Routines, Institutions, Power and Politics, Accounting, Auditing and Accountability Journal, Vol. 13, No. 5, pp. 566-596. 
Reforming Financial Accounts in the Public Sector

Cameron, J. and Guthrie, J. (1993). External Annual Reporting by an Australian University: Changing Patterns, Financial Accountability and Management, Vol. 9, No. 1, pp. 1-15.

Carpenter, V.L. and Feroz, E.H. (2001). Institutional Theory and Accounting Rule Choice: An Analysis of Four US State Governments' Decisions to Adopt Generally Accepted Accounting Principles, Accounting, Organizations and Society, Vol. 26, Nos. 7-8, pp. 565-596.

Christiaens, J. and De Wielemaker, E. (2003). Financial Accounting Reform in Flemish Universities: An Empirical Study of the Implementation, Financial Accountability and Management, Vol. 19, No. 2, pp. 185-204.

Clegg, S.R. (1989), Frameworks of Power, London: Sage Publications.

CNDC (2001). Documento di Presentazione di un Sistema Rappresentativo dei Risultati di Sintesi delle Aziende Non Profit, Milan: Consiglio Nazionale dell'Ordine dei Dottori Commercialisti.

Connolly, C. and Hyndman, N. (2006). The Actual Implementation of Accruals Accounting: Caveats from a Case within the UK Public Sector, Accounting, Auditing and Accountability Journal, Vol. 19, No. 2, pp. 272-291.

Covaleski, M.A. and Dirsmith, M.W. (1988). An Institutional Perspective on the Rise, Social Transformation, and Fall of a University Budget Category, Administrative Science Quarterly, Vol. 33, No. 4, pp. 562-587.

Covaleski, M.A., Dirsmith, M.W. and Samuel, S. (1996). Managerial Accounting Research: The Contributions of Organizational and Sociological Theories, Journal of Management Accounting Research, Vol. 8, pp. 1-35.

Dacin, M.T. (1997). Isomorphism in Context: The Power and Prescription of Institutional Norms, Academy of Management Journal, Vol. 40, No. 1, pp. 46-81.

Denzin, N.K. (1978). The Research Act (Second Edition), New York, NY: McGraw-Hill.

DiMaggio, P.J. (1988). Interest and Agency in Institutional Theory, in L.G. Zucker (ed), Institutional Patterns and Organizations: Culture and Environment, Cambridge, MA: Ballinger Publishing Company.

DiMaggio, P.J. and Powell, W.W. (1983). The Iron Cage Revisited: Institutional Isomorphism and Collective Rationality in Organizational Fields, American Sociological Review, Vol. 48, No. 2, pp. 147-160.

Ezzamel, M., Hyndman, N., Johnsen, Å., Lapsley, I. and Pallot, J. (2005). Accounting, Accountability and Devolution: A Study of the Use of Accounting Information by Politicians in the Northern Ireland Assembly's First Term, Irish Accounting Review, Vol. 12, No. 1, pp. 39-62.

Gray, R. and Haslam, J. (1990). External Reporting by UK Universities: An Exploratory Study of Accounting Change, Financial Accountability and Management, Vol. 6, No. 1, pp. 51-72.

Guthrie, J. and Abeysekera, I. (2006). Content Analysis of Social Environmental Reporting: What is New? Journal of Human Resource Costing and Accounting, Vol. 10, No. 2, pp. 114-126.

Guthrie, J., Petty, R., Yongvanich, K. and Ricceri, F. (2004). Using Content Analysis as a Research Method to Inquire into Intellectual Capital Reporting, Journal of Intellectual Capital, Vol. 5, No. 2, pp. 282-293.

Haigh, M., Carlin, T. and Guthrie, J. (2005). Final Report: Corporations, Fund Managers and the Financial Services Reform Act in Practice and Corporate Social Responsibility, Report of MGSM Centre for Management of Knowledge Capital, Sydney, December.

Hardy, C. (1996). Understanding Power: Bringing About Strategic Change, British Journal of Management, Vol. 7, Special Issue, pp. S3-S16. 
Agasisti, Arnaboldi \& Catalano

Hood, C. (1991). A Public Management for All Seasons?, Public Administration, Vol. 69, No. 1, pp. 3-19.

Hood, C. (1995). The New Public Management in the 1980s: Variations on a Theme, Accounting Organizations and Society, Vol. 20, Nos. 2-3, pp. 93-110.

Jones, R. (1992). The Development of Conceptual Frameworks of Accounting for the Public Sector, Financial Accountability and Management, Vol. 8, No. 4, pp. 249-262.

Jones, R. and Pendlebury, M. (2004). A Theory of the Published Accounts of Local Authorities, Financial Accountability and Management, Vol. 20, No. 3, pp. 305-325.

Jones, D.B., Scott, R.B., Kimbro, L. and Ingram, R.W. (1985). The Needs of Users of Governmental Financial Reports, Stamford, CT: Government Accounting Standards Board.

Lapsley, I. (1998). Reforming the Public Sector: Demon Accountants at Work?, Irish Accounting Review, Vol. 5, No. 1, pp. 115-131.

Lapsley, I. and Oldfield, R. (2001). The Accountant's Craft in the New Public Sector, Irish Accounting Review, Vol. 8, No. 1, pp. 1-32.

Leblebici, H., Salancik, G.R., Copay, A. and King, T. (1991). Institutional Change and the Transformation of Interorganizational Fields: An Organizational History of the U.S. Radio Broadcasting Industry, Administrative Science Quarterly, Vol. 36, No. 3, pp. 333-363.

Lye, J., Perera, H. and Rahman, A. (2005). The Evolution of Accruals-Based Crown (Government) Financial Statements in New Zealand, Accounting, Auditing and Accountability Journal, Vol. 18, No. 6, pp. 784-815.

Mack, J. and Ryan, C. (2006). Reflections on the Theoretical Underpinnings of the GeneralPurpose Financial Reports of Australian Government Departments, Accounting, Auditing and Accountability Journal, Vol. 19, No. 4, pp. 592-612.

Mayston, D. (1992). Capital Accounting, User Needs and the Foundations of a Conceptual Framework for Public Sector Financial Reporting, Financial Accountability and Management, Vol. 8, No. 4, pp. 227-248.

Mellett, H. (1997). The Role of Resource Accounting in the UK Government's Quest for Better Accounting, Accounting and Business Research, Vol. 27, No. 2, pp. 157-168.

Meyer, J.W. and Rowan, B. (1977). Institutionalised Organizations: Formal Structure as Myth and Ceremony, American Journal of Sociology, Vol. 83, No. 2, pp. 340-363.

Meyer, J.W. and Scott, W.R. (1992). Centralization and Legitimacy Problems of Local Government, in J.W. Meyer and W.R. Scott (eds), Organizational Environment: Ritual and Rationality, London: Sage Publications.

MIUR (2005). Indagine sui Sistemi Contabili, Rome: MIUR Ministero dell'Università e della Ricerca.

Pallot, J. (1994). The Development of Accrual-Based Accounts for the Government of New Zealand, Advances in International Accounting, Vol. 7, No. 2, pp. 287-308.

Parker, L. and Guthrie, J. (1990). Public Sector Accounting and the Challenge of Managerialism, in J. Forster and J. Wanna (eds), Budgetary Management and Control, Melbourne: Macmillan.

Ribeiro, J.A. and Scapens, R.W. (2006). Institutional Theories in Management Accounting Change: Contributions, Issues and Paths for Development, Qualitative Research in Accounting and Management, Vol. 3, No. 2, pp. 94-111.

Roberts, P.W. and Greenwood, R. (1997). Integrating Transaction Cost and Institutional Theories: Toward a Constrained-Efficiency Framework for Understanding Organizational Design Adoption, Academy of Management Review, Vol. 22, No. 2, pp. 346-373. 
Reforming Financial Accounts in the Public Sector

Ryan, C. (1998). The Introduction of Accrual Reporting Policy in the Australian Public Sector: An Agenda Setting Explanation, Accounting, Auditing and Accountability Journal, Vol. 11, No. 5, pp. 518-539.

Scott, R. and Meyer, J. (1994). Institutional Environments and Organizations, Thousand Oaks, CA: Sage Publications.

Skærbæk, P. (2005). Annual Reports as Interaction Devices: The Hidden Constructions of Mediated Communication, Financial Accountability and Management, Vol. 21, No. 4, pp. 385-411.

Venieris, G. and Cohen, S. (2004). Accounting Reform in Greek Universities: A Slow Moving Process, Financial Accountability and Management, Vol. 20, No. 2, pp. 183-204. 